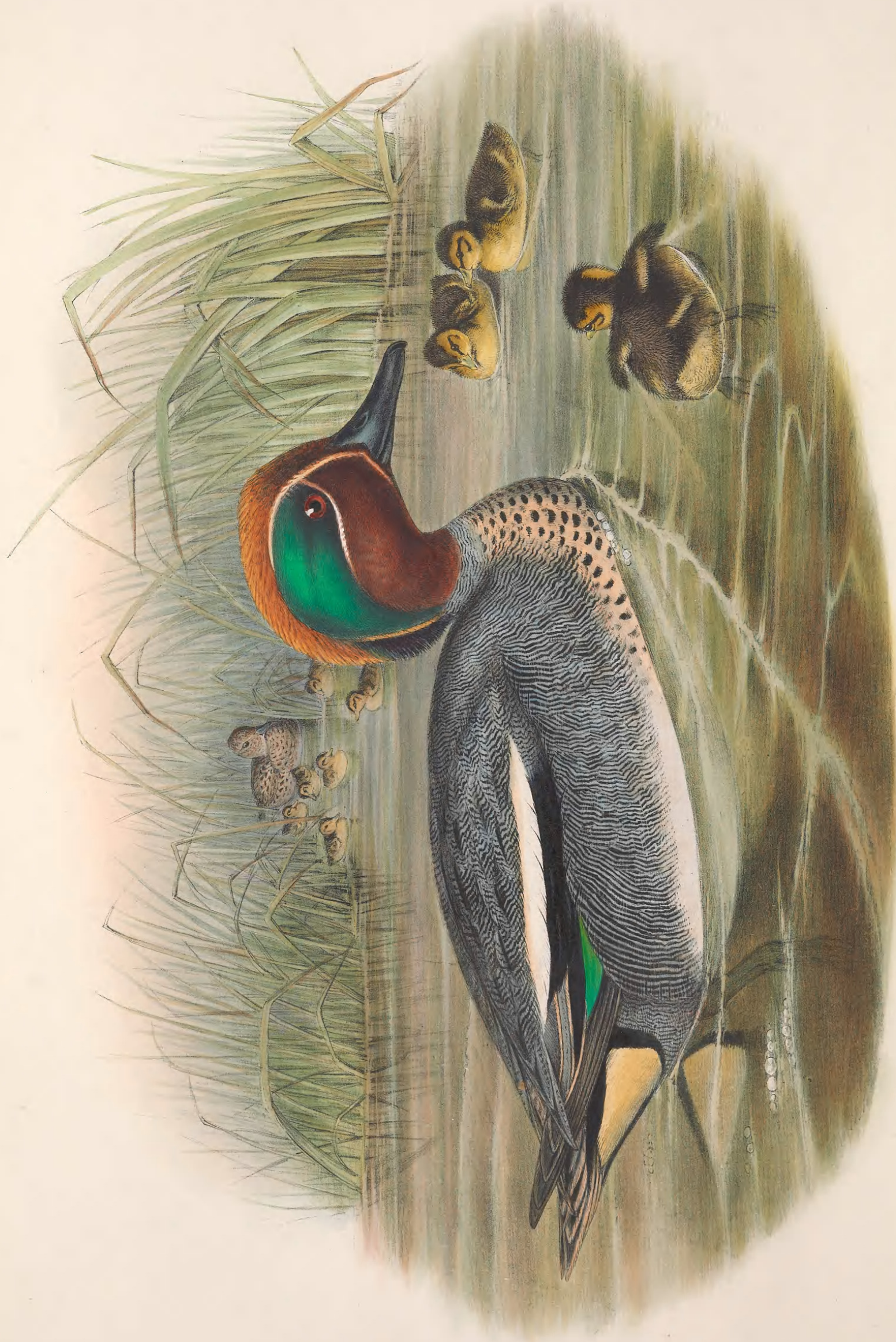

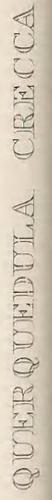




\section{QUERQUEDULA CRECCA.}

Teal.

Anas Crecca, Linn. Syst. Nat, tom. i. p. 204.

Querquedula minor, Briss. Orn., tom. vi. p. 436, pl. 40. fig. 1.

secunda, Ray, Syn., p. 147, A 6 .

crecca, Steph. Cont. of Shaw's Gen. Zool., vol. xii. p. 146

crecca, subcrecca, et creccoides, Brehm, Handb. der Naturg. Vög. Deutschl., pp. 884, 885, 886

The Teal is the least of the Ducks inhabiting the British Islands, and is much valued for the beauty of its plumage, the elegance of its contour, and the delicate flavour of its flesh. The collector places his mounted specimen in the most conspicuous part of his museum, and the sportsman is often induced to leave his marked-down Woodcock for the chance of a shot, should a flight of Teal splash into the neighbouring rivulet, or circle over the moor.

Although not a cosmopolitan, this pretty little Duck enjoys a very wide range over the Old World, and, besides being generally dispersed in our islands, is equally numerous in similar latitudes in all the countries lying eastward of us, as far as China and Kamtschatka; northward it proceeds to the regions of the Arctic circle, and southward to the verge of the equator; in a word, it is found in Morocco, Algeria, Egypt, Asia Minor, Persia, and India, as well as in Europe. In all these countries its flesh is highly prized, and consequently much sought for as an article of food. It is plain, therefore, that if the Teal did not extend its range to thinly peopled countries, and select sites for the duty of incubation which are difficult of detection, it would soon become extirpated. The Rook and the Heron nidify in the most conspicuous places, and the cradles for their young are so prominently displayed that they may be seen from a great distance; the Teal, on the contrary, resorts to the most secluded situations for this purpose; and hence it is the bird still continues so abundant, and that such large numbers are annually sent to our markets during the autumn and winter months. To what cause are we to assign the delicate flavour of the Teal ? It is most probably due to the nature of the food upon which it subsists: this is neither fish nor any animal substances that can impart a strong or rancid flavour, as in the case of those species of the family whose lives are spent upon the seas-Scoters, Eiders, \&c. No; the food the Teal consists of the points of the finest grasses, the leaves of water-plants, seeds, grain, insects, small freshwater mollusks, and probably worms.

As autumn approaches, the rivers, rivulets, and the great ponds of the woodlands and open moors are all more or less resorted to by the Teal in small parties of eight or ten in number, or in flights of fifty or more. In these situations, the birds, if unmolested, remain during the entire day on the surface of the water, rising and falling with every ripple, or sitting on the banks; as evening approaches, they become more animated, and the whistling erick of the male is heard; and when night begins to throw a veil over the face of nature, they simultaneously rise, and quit the waters for the morass, the ploughed field, the oozy mud-bank, or wherever they may obtain a supply of food; at daylight they return to their usual sanctuary, where they preen their feathers, and the males swim round each other in circles before settling to rest for the day.

These latter remarks apply to the bird as seen with us in autumn and winter, when it has partially or wholly left the northern parts of our islands for the more temperate ones of the south. As spring approaches, most of those that have escaped the gunner and the devices of the decoy-man return again to the places of their former resort, and there incubate in all suitable situations. Some, however, stay and breed in many of the counties of England and Ireland. The site chosen is sometimes on the hill-side, in the neighbourhood of a river or loch, at others far away out on the heath or on the moor, even to the distance of many miles, the slight nest being placed in the midst of the heather, in a tussock of grass, or any other herbage that may effectually screen it from sight. A little rill of water may perchance be close at hand, or a wet sloppy morass or a pool not far off, to which the young, on their exclusion from the egg, are immediately conducted, and where they are most assiduously guarded by their parents from the attacks of harriers and any other animals by which their lives may be endangered; but the voracious pike, which often abides in such situations, not unfrequently lessens their number. At Scoulton Mere, in Norfolk (celebrated for one of the largest colonies of Black-headed Gulls in England), several pair breed annually, and the proprietor, Major Weyland, affords them strict protection. Their nests are usually placed in the shrubberies and plantations which surround the Mere.

"The Teal," says Mr. Lubbock, " is taken every year in great numbers in our decoys, in that at Winterton, in particular, where more than two hundred have been caught at once in a single pipe. Although it 
congregates in immense numbers, in decoys it does not fly in such large flocks as many other Ducks, from twenty to twenty-five Teal being a considerable number. I have once known of a flock of sixty, but this is a very singular occurrence."

Unlike most other kinds of birds, all the Ducks undergo a second seasonal change, and the Teal among their number: during the spring and the early part of summer the male is dressed in gay attire, which, after the breeding-season, is exchanged for a more sombre livery, so closely assimilating to that of the female that it is not easy to distinguish one sex from the other; this plumage is carried until late in the autumn, when it is again exchanged for the gayer dress.

The flight of the Teal is dashing and spirited; it rises directly from the water, and flies off in a straight line, or threads with vast facility through the branches of the alders and other trees growing by the sides of the little nooks and secluded places in which it is frequently flushed. Wonderfully rapid, indeed, is the flight of this bird when fairly on the wing, or when it comes sweeping round the sportsman, who may be on the qui vive for a shot, and who must be quick, indeed, if he wishes to bag any of the flight.

On the water the Teal is light and buoyant, swimming high above the surface, and displaying its fine plumage to the greatest advantage, particularly the beautiful buff stripe near the scapularies of the male; on the land it has none of the awkward gait of the diving-ducks, but walks with ease and comparative elegance of movement.

The Teal readily becomes semi-domesticated, and will breed in the ponds and lakes of the pleasureground, even in such situations as the Zoological Gardens in the Regent's Park. The decoys, in which the greater number sent to our markets are taken, differ much in their character; some are great open sheets of water, like Fritton in Suffolk, while others comprise a number of ponds, as at Nacton in the same county. In that first named, Mallards, Pintails, Widgeon, and Teal are often to be seen indiscriminately mingled; but at Nacton it is far otherwise: there each pond is tenanted almost exclusively by a single species, the Teal always going to the smallest and the highest up the glen-a circumstance of great advantage to the owner, G. Tomline, Esq., who, through his clever decoy-man, Skelton, can obtain a dozen Teal any morning he pleases, without disturbing the Mallards and other birds below. I shall not easily forget how much I was interested by the sight presented to me on visiting this peculiar decoy, nor Mr. Tomline's kindness in forwarding to me from time to time examples of all the Duck tribe, taken therein in their finest states of plumage, for the furtherance of the present work-an act of courtesy and liberality which I have much pleasure in here acknowledging.

"The well-known Teal," says Mr. Jerdon, “is one of the most abundant of the visitors to India. It frequents tanks and rivers, often in immense flocks. Large numbers are netted or caught in various ways to supply the Tealeries. It is strictly a night-feeding species; and about sunset immense flocks may be seen and heard flying in different directions to their feeding-grounds." In Cunningham's 'Ladakh, Physical, Statistical, and Historical,' it is mentioned that he "shot three Teal on the Saraj Dal, a small lake at the head of the river Bhága, at an altitude of 16,000 feet."

That ardent lover of nature, and excellent sportsman, St. John, speaking of the Teal as seen by him in Sutherlandshire, says it " can scarcely be called a winter bird with us, although occasionally a pair or two appear; but in spring they come in numbers to breed and rear their tiny young in the swamps and lochs. Nothing can exceed the beauty and neatness of this miniature Duck. It flies with great swiftness, rising suddenly into the air when disturbed, and dropping as quickly after a short flight. In spring the drake has a peculiar whistle; at other times the note is a loud quack. A pair of Teal, if undisturbed, will return year after year to the same pool for the purpose of breeding. Like the wild Duck, they sometimes hatch their young a considerable distance from the water, and lead them immediately to it. In some of the mountain lakes the Teal breed in great numbers. When shooting in August, I have occasionally seen a perfect cloud of these birds rise from some grassy loch."

The eggs are of a lengthened form, measuring one inch and nine lines in length by one inch and four lines in breadth: they are of a creamy white, and eight to twelve in number. The nest is composed of grasses, pieces of flags and various kinds of herbaceous plants, and lined with down and feathers.

In North America our Teal is represented by a distinct species, the Querquedula Carolinensis, which much resembles it; but the males of the Transatlantic bird are easily recognized by the absence of the buff stripes on the back, and the presence of a light-coloured crescent on either side of the breast, just in front of the wing.

The accompanying. Plate represents a male and a brood of young, of the size of life, with a reduced figure of a female in the distance. 


\section{$2 \mathrm{BHL}$ Biodiversity Heritage Library}

Gould, John. 1873. "Teal 16, Querquedula crecca [PI. 16]." The birds of Great Britain 5, -. https://doi.org/10.5962/p.324060.

View This Item Online: https://www.biodiversitylibrary.org/item/222497

DOI: https://doi.org/10.5962/p.324060

Permalink: https://www.biodiversitylibrary.org/partpdf/324060

\section{Holding Institution}

Smithsonian Libraries

\section{Sponsored by}

Biodiversity Heritage Library

\section{Copyright \& Reuse}

Copyright Status: Public domain. The BHL considers that this work is no longer under copyright protection.

This document was created from content at the Biodiversity Heritage Library, the world's largest open access digital library for biodiversity literature and archives. Visit BHL at https://www.biodiversitylibrary.org. 